\title{
An empirical review of lean manufacturing and their strategies
}

\author{
Virender Chahal $^{a^{*}}$ and M.S. Narwal ${ }^{\mathrm{b}}$
}

${ }^{a}$ Research Scholar Department of Mechanical Engineering, Deenbandhu Chhotu Ram University of Science and Technology, Sonipat, Haryana, India

${ }^{b}$ Associate professor, Department of Mechanical Engineering, Deenbandhu Chhotu Ram University of Science and Technology, Sonipat, Haryana, India

\section{H R O N I C L E}

Article history:

Received: February 1, 2017

Received in revised format:

March 16, 2017

Accepted: April 25, 2017

Available online:

April 26, 2017

Keywords:

Lean Concept

Lean strategies

Lean waste

Lean barriers and Lean imple-

mentation

\section{A B S T R A C T}

The theory of lean manufacturing provides the quality of the products in minimum cost and provides customer satisfaction. Today, the competition level is very high and every industry tries to supply high quality products in nominal cost, so lean is the latest tool to achieve. The objective of this paper is to study different lean concepts under various lean strategies. This study helps to find out the status of lean manufacturing and its ways of implementation. Also in this paper, there is a discussion about lean manufacturing concept, lean waste, lean strategies, lean barriers and cycle of lean implementation. This paper presents a literature review to clear the status of lean manufacturing and their strategies with help of collection of relevant papers.

(C) 2017 Growing Science Ltd. All rights reserved.

\section{Introduction}

Lean manufacturing is a discrepancy on the idea of efficiency based on optimizing flow. Lean manufacturing help to attract manufacturing operations and pick up the industrial jobs and customer satisfaction (Sing et al., 2010). When lean manufacturing is successfully followed, there is a good growth in the quality and the output productivity and also reduction in the completed wares inventory and work process (Seth \& Gupta, 2005). The main goal of lean manufacturing is to help out the manufacturers who wish to progress the industry operations and best quality with good customer satisfactions in less amount. In manufacturing sector, there were new philosophies to produce maximum quantities by creating fewer unwanted activities. Proper implementation of different parameters profit will be much more (Delattre, 2002). Lean manufacturing lifts in overall production output and power up customer and the employee's job satisfaction (Soriano-Meier et al., 2002; Singh et al., 2010; Rose et al., 2013).

\footnotetext{
* Corresponding author.

E-mail address: vchahal68@gmail.com (V.Chahal) 
After the finishing of World War 2, lean manufacturing was developed by Japanese manufacturers mainly in automotive industry. That time was a problem of shortage of materials, money and human resources. In Toyota motor company, Eiji toyoda and Taiichi ohno set a concept of "Toyota Production System", and today known as "Lean Manufacturing." The main concept after the system is to eliminate the wastage. After the quick success of lean manufacturing in Japan, other firms and industries, mainly in US, copied this amazing system. The expression "Lean" is defined as less utilization, in term of all inputs, to create the same outputs, as those shaped by a predictable mass production system, while contributory increased varieties for the end customer. The performance of smooth flow finds out quality problems that previously existed, and thus waste decline naturally happens as an end result. Lean Manufacturing (LM) has been widely recommended by different industries because LM eliminates waste without additional requirements of resources (Bhamu \& Sangwan, 2012; Vamsi et al., 2014).

Current world is going from an era of disconnect national economies to the networked world economy. The beginning of liberalization, privatization and globalization has brought forth profound economic, social, environmental and technological pressures on the organizations. Competition has become more difficult, stronger and the customers are more demanding. Rivalry is severed in all aspects of production such as cost, quality of service product and technology (Poksinska, 2010; Pekuri et al., 2012).

\subsection{Lean Manufacturing Strategies}

When lean manufacturing concept was developed the main question was that which strategies will be more successive for this concept. After study literature, the result was in form of the number of strategies which can be used here. So this lean concept becomes a flexible system in which the strategies can be added, merged and be further explored as per requirement. Some lean strategies are:
- $5 S$
- Automation
- Continuous Flow
- Continuous Improvement
- Kan-Ban
- Kaizen
- $\quad$ Single Minute Exchange to Die (SMED)
- Cellular Manufacturing
- Six Sigma
- Team Development/Training
- Total Productive Maintenance

- $\quad$ Total Quality Management (TQM)

- Value Stream Mapping (VSM)

- Visual Management

- Work Standardization

- Flexible manufacturing System (FMS)

- Production leveling

- Inventory Management

- Zero Defect Concepts

- WIP (Work in Process)

- Lean Thinking

In this paper, the main focus is on meaning of lean and its relative terms. There are also some benefits and barriers appear in lean implementation in industries. Some methods and principles are also discussed. Lean manufacturing is very necessary in today's market for manufacturers because this is only one strategy to survive in this competition. Lean manufacturing also focuses to achieve zero waste concept and provides better quality and benefits to customers as well as industry. That's why, this paper tries to give a good review of lean manufacturing for those industries that are following Lean manufacturing or wish to implement Lean in industry.

\section{Methodology}

This research paper is based on the literature review of lean manufacturing. The complete details were collected by following the number of journals worldwide, national and international conferences, internet and proceedings. In initial stage, there are so many innovation ideas through web and books which provided desirable recourses in research. The optimal solution has been identified by literature review. This paper will help to understand the concept of lean manufacturing, its enablers and barriers 
for implementation in industry. The solution is found by studying of numbers of papers on lean implementation, their effects with enabler and barriers. There are more than 25,000 research papers related to lean manufacturing. Then we select those research papers which are directly related to research work. The papers were selected from year 1997 to 2015 which are related to lean manufacturing, leanness, lean implementation, their strategies and lean wastes. All papers are directly collected from Google scholar and related searches. After that we select 102 papers which are related to research work in which lean manufacturing introduction and lean study papers are 28 , lean manufacturing implementation papers are 19 , lean strategies/tools \& techniques papers are 26 , lean relation with other strategies papers are 2, and leanness measurement papers are 29. The motive of this paper is to provide better understanding of lean and their strategies for research as well as industry.

\section{Literature Review}

The thought process of lean was thoroughly described in the book "The Machine That Changed the World” by James P. Womack, Daniel Roos and Daniel T. Jones in 1990.

In a subsequent volume, "Lean", by James P. Womack and Daniel T. Jones, in 1996. According these books, there are further divided lean principles:

- Specify the value desired by the customer

- Identify the value stream for each product providing that value and challenge all of generally nine out of ten) currently necessary to provide it

- Make the product flow continuously through the remaining value-added steps

- Introduce pull between all steps where continuous flow is possible

- Manage toward perfection so that the number of steps and the amount of time and information needed to serve the customer continually falls

\section{Effective steps for lean manufacturing implementation}

There are some effective steps:

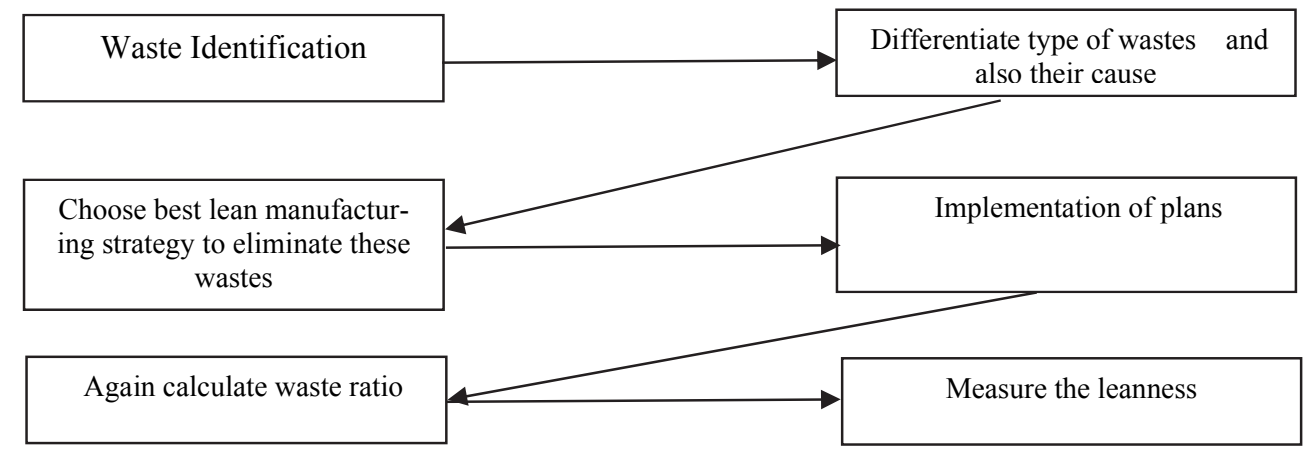

Fig. 1. Lean manufacturing implementation

Waste Identification: Every industry knows that there is some waste but not able to find out all types of hidden and unhidden wastes in industry.

Differentiate type of wastes and also their cause: This is very important to differentiate all types of waste and their causes. If the cause is eliminated then automatically waste will be reduced. There are so many techniques to eliminate different wastages. 
Choose best lean manufacturing strategy to eliminate these wastes: In this step, we select a suitable lean manufacturing strategy for the identified wastes. There are many techniques which will give optimum solution for this plan. So we make appropriate plan for elimination.

Implementation of plans: After making plan, next step is implementation the plan.

Again calculate waste ratio: Compare the current waste status with past record.

Leanness measurement: Leanness can be measured with different lean measure techniques.

There are so many techniques which are used in Lean manufacturing. Many authors used different techniques to show the current status of developing countries. Bayou and Korvin (2008) presented the paper which shows the manufacturing leanness is a strategy used to achieve goals in less input to better output. The leanness measurement calculated by seven characteristics: relative, dynamic, long-term fuzzy logical, objective, integrative and comprehensive. Singh et al. (2010) presented a study of lean implementation and benefits in industry with the help of lean tool, value stream mapping (VSM). Paper presented to states of industry: current and future state. This presented the effect of VSM as very effective tool for Lean manufacturing.

\subsection{Lean Manufacturing Cycle for Collected Literature Review}

According to Karim and Arif-Uz-Zaman (2013), there are some effective methodologies and ways to implement lean manufacturing. But before implementation, we should know what way of implementation is. Lean manufacturing area is very vast but how and which data should be collected from literature, which types of barriers will be there and how solve these, why proper lean implementation is necessary etc., these are all questions which must be cleared in mind. The collection mode is written in below diagram and can implement lean according to this given cycle.

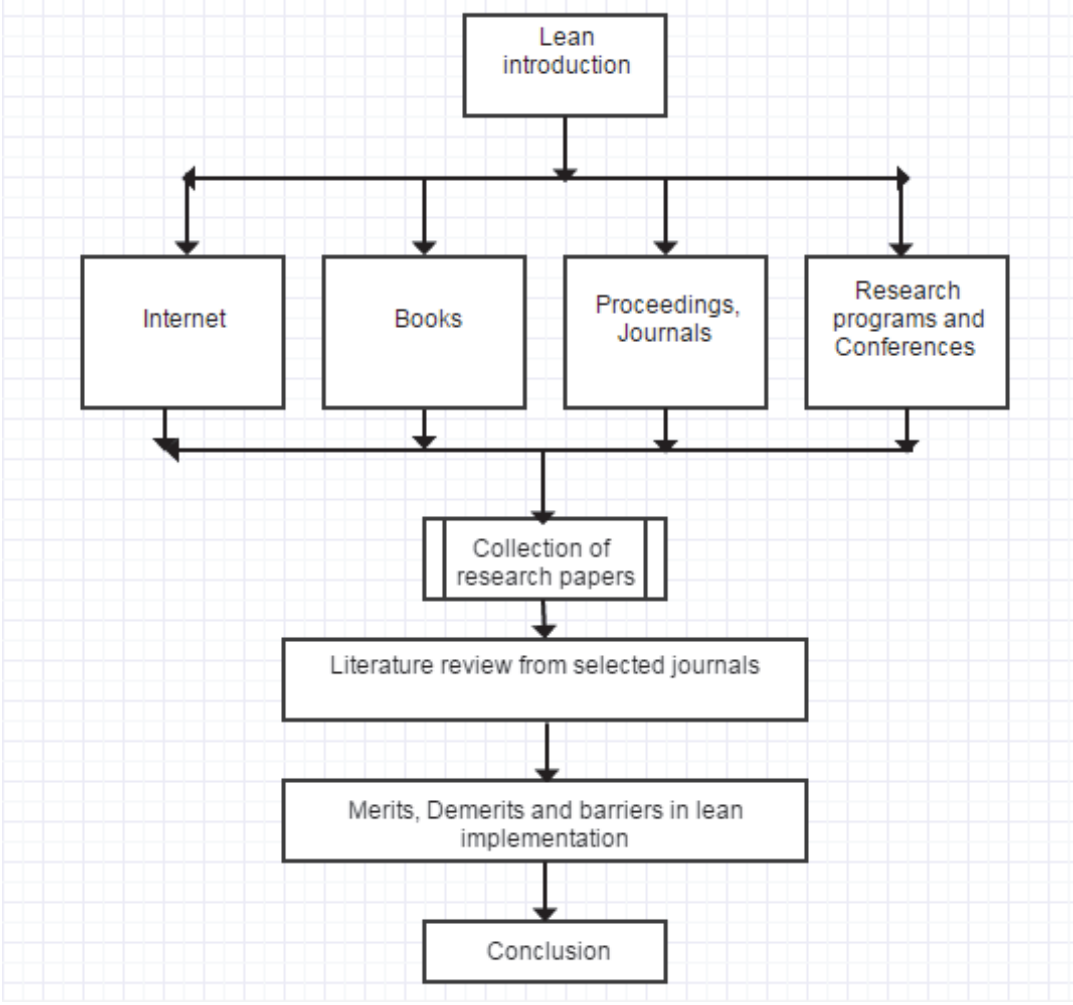

Fig. 2. Lean Manufacturing cycle for collected literature review 


\subsection{Seven Wastes of Industries}

What is industrial waste and why they measures? It is very important question. In simple way," Any unnecessary action which produces unnecessary result called as waste". And lean manufacturing is also developed to eliminate these wastes. According to Hines and Rich (1997), there are basically seven lean industrial wastes which can be eliminated. They impact on industrial performance and reduce industrial output. Waste is nothing but its undesirable actions which are deeply studied below. Lean implementation can't be completed until all waste is removed. But before elimination, it should be know about all wastes which are:

The following are the seven wastes, as categorized by Taiichi Ohno:

- Overproduction - Manufacture of products in advance or in excess of demand wastes money, time and space. Overproduction happens when industry produces more than demanded product for future which affect total system. Mostly manufacturers have a reason to manufacture more but most of time it gives loss.

- Waiting - Processes are ineffective and time is wasted when one process waits to begin while another finishes. Instead, the flow of operations should be smooth and continuous. According to some estimates, as much as 99 percent of a product's time in manufacture is actually spent for waiting. Waiting for job plan, order, machine parts, e-mail etc., these all are the waiting waste.

- Transportation - It's a movement of tools, machine parts, product between workstations which are non-value added activities. It is costly and may be a cause of accident. Movement of material from one work place to another is a waste of time and money.

- Inappropriate/over processing - It is a type of waste in which extra processing happens to make it perfect which is expensive. Sometimes, it creates extra waste in form of labor, material, time and money. This processing occurs significant amount of time to take it in shape and, many times, whole system is disturbed.

- Excessive inventory - Wastes funds viva carrying costs of inventory storage and preservation. Main important thing to remember is that, inventory is not only in form of raw materials but also finished goods.

- Unnecessary motion - Resources are done in when workers have to twist, take an unnecessary motion from workstation distances to other place. Workplace ergonomics appraisal should be conducted to plan more capable surroundings. Other examples include the following:

1. Re-assembling or arrangement of machine parts to get them into a new manner.

2. Motion between work stations to get machine tools and parts.

3. Placing all notes and files al right place.

4. Placing tools nearby.

- Defects - Defects generally happen but not good when they repeat. They provide poor quality, bad customer satisfaction and loss to industry. They also affect sale and price of product. The market value and reliability also decreased. Lean manufacturing is based on a combination of different processes to make industry defect free.

\subsection{Techniques used in Lean Manufacturing}

According to Paez et al. (2005), Mahdiloo et al. (2014) Miller et al. (2010) and Anand and Kodali (2009), there are so many techniques available in literature but there are some important strategies discussed below which are mostly used. In Table 1, there are some techniques correlated with their requirements. 


\section{Table 1}

The summary of lean manufacturing techniques and requirements

\begin{tabular}{|c|c|c|}
\hline S. No & Lean Manufacturing Techniques & Requirements \\
\hline 1 & $5 \mathrm{~S}$ & Reduce wasted time \& motion. \\
\hline 2 & Automation & Reduce human effort and provide accurate automatic system. \\
\hline 3 & Continuous Flow & Ensuring the continuous flow throughout the value stream. \\
\hline 4 & Continuous Improvement & Make sure that there is every little improvement every day and improve overall efficiency. \\
\hline 5 & Kan-Ban & Schedule production and minimize work-in-process. \\
\hline 6 & Kaizen & Change for better every day. \\
\hline 7 & $\begin{array}{l}\text { Single Minute Exchange to Die } \\
\text { (SMED) }\end{array}$ & $\begin{array}{l}\text { To minimize setup time and cost thereby freeing capacity and enabling the production of very } \\
\text { small lots. }\end{array}$ \\
\hline 8 & Cellular Manufacturing & Design cells to optimize process for better performance. \\
\hline 9 & Six Sigma & Improve quality, operational performance, practices and systems. \\
\hline 10 & Team Development/Training & Motivated team has better knowledge of work. \\
\hline 11 & Total Productive Maintenance & Ensure uptime, Improve process capability and consistency \\
\hline 12 & Total Quality Management (TQM) & Improve quality by preventing defects from occurring. \\
\hline 13 & $\begin{array}{l}\text { Value Stream Mapping } \\
\text { (VSM) }\end{array}$ & Visualize of processes and their conformance to lean manufacturing principles. \\
\hline 14 & Visual Management & $\begin{array}{l}\text { To provide immediate, visual information that enables people to make correct decisions and man- } \\
\text { age their work and activities. }\end{array}$ \\
\hline 15 & Work Standardization & $\begin{array}{l}\text { To ensure that all workers execute their tasks in the same manner and thus reduce variation from } \\
\text { differences in work method. }\end{array}$ \\
\hline 22 & Flexible manufacturing System (FMS) & $\begin{array}{l}\text { To provide a systematic flexible change in manufacturing environment like layout, methods, } \\
\text { machine etc. }\end{array}$ \\
\hline 16 & Production leveling & Reduce unevenness and waste in industry. \\
\hline 17 & Inventory Management & Put all inventory products in a proper sequence to supply these items in proper network. \\
\hline 18 & Zero Defect Concept & To eliminate all possibility which are responsible for wastage. \\
\hline 20 & WIP (Work in Process) & WIP is the summation of all investment factors i.e. all types of costs puts during process. \\
\hline 21 & Lean Thinking & Discover new ideas to deliver much comfort level and benefits to industry with eliminating waste. \\
\hline
\end{tabular}

\subsection{Lean focused area}

As per the study of literature review of lean we have used 102 research papers and the research found that there had been very few areas which focused on practical lean implementation. It was also found that almost lean manufacturing study is divided in basic three areas; Survey, Philosophy and case study. In Fig. 3, the results show that case study is most focused area. According to Gupta and Jain (2013), most of studies are done on case study of different lean manufacturing firms, then survey based study was done and at last not least lean philosophy study was done. But there is a lack of new and practical innovation about lean manufacturing strategies. The below diagram shows the status of lean manufacturing.

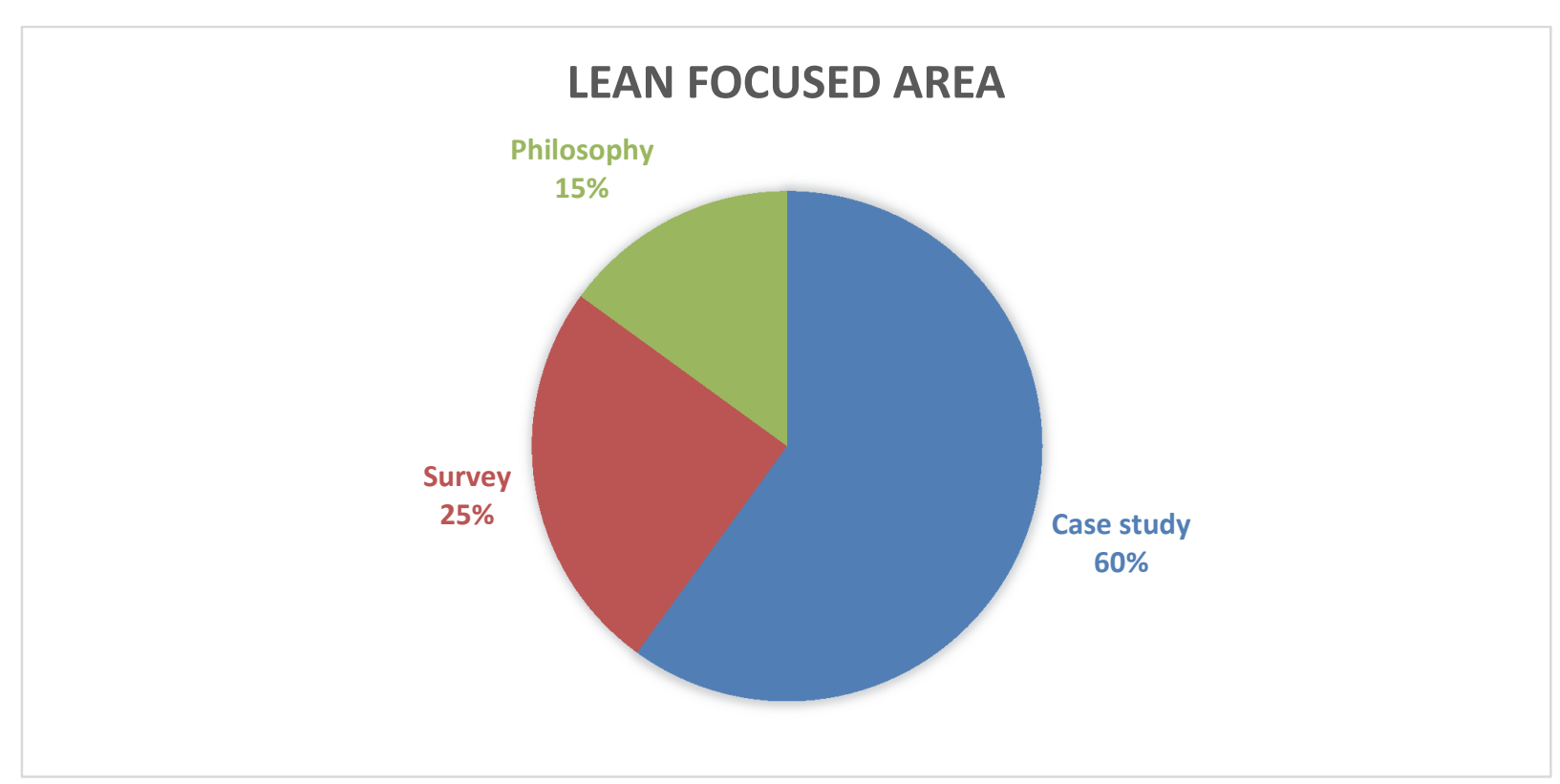

Fig. 3. Lean focused area 


\subsection{Technique highlights by Literature for different waste}

There are many authors providing important information about lean and lean strategies. From literature study, it is clear that these lean strategies will eliminate different types of industrial waste and they are correlated. Here some papers are collected from literature review which is directly or indirectly related to lean manufacturing. The collections of these papers are based on only lean as master concept. There are also some individual techniques of lean in terms of the number of papers but they are specially related to eliminate respected waste which mention in literature of lean manufacturing. All data is differentiated in lean technique used by different authors. Some authors provide depth detail about used lean strategies and some gives only little introduction about used lean strategy. Main goal is to provide status of lean manufacturing between years, 1997-2015, by collecting some papers. These papers detail provides some interest of different authors also. And these all details are filled in Table 2 as follows,

\section{Table 2}

The literature review

\begin{tabular}{|c|c|c|c|c|c|c|c|c|c|c|c|c|c|c|c|c|}
\hline & Lean Strategies & 1 & 2 & 3 & 4 & 5 & 6 & 7 & 8 & 9 & 10 & 11 & 12 & 13 & 14 & 15 \\
\hline 1 & Hines and Rich (1997) & & & & & & & & V & & & & & & & \\
\hline 2 & Stewart \& Adams (1998) & & & & $v$ & & & & & & & & & & & \\
\hline 3 & Naylor et al. (1999) & & V & $\sqrt{ }$ & & & & & & & & & & & & \\
\hline 4 & Hines et al. (1999) & & & & & & & & $\mathrm{V}$ & & & & & & & \\
\hline 5 & Vrijhoef and Koskela (2000) & & v & & & & & & & & & & & & & \\
\hline 6 & Bob Carroll (2001) & & & & & V & & & & & & & & & & \\
\hline 7 & Meier \& Forrester (2001) & & v & & & v & & & & & & & & & & \\
\hline 8 & Aitken et al. (2002) & & V & & & & & & & & & & & & & \\
\hline 9 & Fullerton et al. (2003) & & V & & & & & & & & v & & & & & \\
\hline 10 & Shah and Ward (2003) & & V & & & $\mathrm{V}$ & & $\mathrm{V}$ & & & & & & & & \\
\hline 11 & Paez et al. (2004) & & & & & v & & v & v & & & & & & & \\
\hline 12 & Paez et al. (2005) & & & & & V & V & & & & & & & & & \\
\hline 13 & Goldberg et al. (2006) & & & & & & & & V & & & & & & & \\
\hline 14 & Abdulmaleka and Rajgopalb (2007) & & & & & & & & V & & & & & & & \\
\hline 15 & Wan \& Chen (2008) & & $\mathrm{V}$ & V & & & & & V & & & & & & & \\
\hline 16 & Sahoo et al. (2008) & & & & & & & & V & & & & V & & & \\
\hline 17 & Gautam \& Singh (2008) & & & & & & & & & & & $\sqrt{ }$ & & & & \\
\hline 18 & Pettersen (2009) & & & & & V & & & & & & & & & & \\
\hline 19 & Kodali (2009) & & V & & & V & & v & & & & & & $\sqrt{ }$ & & \\
\hline 20 & Pattanaik \& Sharma (2009) & & & & & & & & $\mathrm{V}$ & & & & & & & \\
\hline 21 & Nordin et al. (2010) & & V & & & $\mathrm{V}$ & & $\mathrm{V}$ & & & & & & & & \\
\hline 22 & Ramnath et al. (2010) & & & $\sqrt{ }$ & & & & & & & & & & & & \\
\hline 23 & Singh et al. (2010) & & V & & V & & & & & & $\sqrt{ }$ & & & & & \\
\hline 24 & Singh et al. (2010) & & & & V & & & & & V & & & & & V & \\
\hline 25 & Zanjirchi et al.(2010) & & v & & & v & & $v$ & v & & & & & & & \\
\hline 26 & Chauhan et al.(2010) & & & & & & & & & $v$ & v & & & & & \\
\hline 27 & Detty \& Yingling (2010) & V & V & & V & & & & & & & & & & & \\
\hline 28 & Nordin et al.(2010) & V & & & V & & & & & V & & & & & & \\
\hline 29 & Behrouzi and wong (2010) & & v & $\sqrt{ }$ & & & & & & & & & & & & \\
\hline 30 & Seyedhosseini et al. (2011) & & V & & & & & & & & & & & & & \\
\hline 31 & Vinodh \&Balaji (2011) & 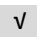 & 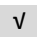 & $\checkmark$ & V & V & V & $v$ & & & & & & & & \\
\hline 32 & Yang et al.(2011) & & $\mathrm{V}$ & $\sqrt{ }$ & & $\mathrm{V}$ & & & & & & & & & & \\
\hline 33 & Schwarz et. al. (2011) & & & & & V & & $v$ & V & & & & & & & \\
\hline 34 & Vinodh \& Chintha (2011) & V & V & $\sqrt{ }$ & V & V & V & & & & & & V & & & \\
\hline 35 & Cuaa et al. (2011) & & v & & & v & & $v$ & & & & & & & & \\
\hline 36 & Vinodh \& Joy (2011) & V & V & $\checkmark$ & V & V & & $v$ & & & & & & & & \\
\hline 37 & Kumar et al. (2011) & & $\mathrm{V}$ & $\sqrt{ }$ & & & & & & & & & & & & \\
\hline 38 & Eswaramoorthi et al. (2011) & & $\mathrm{V}$ & & V & & & & & & v & & & & & \\
\hline 39 & Rajenthirakumar \&Thyla (2011) & & & & & & & & & & & $\sqrt{ }$ & & & & \\
\hline 40 & Goriwondo et al. (2012) & & & & & V & & v & V & & & & & & & \\
\hline 41 & Gopinath \& Freiheit (2012) & & V & $\sqrt{ }$ & V & V & & & & & & & & & V & \\
\hline 42 & Alaskari et al. (2012) & V & V & $\sqrt{ }$ & V & & V & & & & v & & & & & \\
\hline 43 & Satao et al. (2012) & 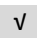 & & $\checkmark$ & & & & $v$ & & & & & & & & \\
\hline 44 & Mohanraj \& Sakthivel (2012) & & & & & $\mathrm{V}$ & & $\mathrm{V}$ & $\mathrm{V}$ & & & & & & & \\
\hline 45 & Ghosh (2012) & V & V & $\sqrt{ }$ & V & V & V & $v$ & & & $\sqrt{ }$ & & & & & \\
\hline 46 & Vinodh \& Vimal (2012) & V & $\mathrm{V}$ & $\sqrt{ }$ & V & $\mathrm{V}$ & V & $\mathrm{V}$ & & & $\checkmark$ & & & & & \\
\hline
\end{tabular}


Table 2

The literature review (Continued)

\begin{tabular}{|c|c|c|c|c|c|c|c|c|c|c|c|c|c|c|c|c|}
\hline 47 & Jainury et al. (2012) & & $\mathbf{v}$ & & $\mathbf{v}$ & & & & & & $\mathbf{v}$ & & & & & \\
\hline 48 & Gupta \& Jain (2013) & $\mathrm{v}$ & $\mathrm{v}$ & $\mathrm{v}$ & $\mathrm{v}$ & $\mathrm{v}$ & $v$ & & & & $\mathrm{v}$ & & & & & \\
\hline 49 & Karim and Zaman (2013) & & & & & & & $v$ & $v$ & & & $v$ & & & & \\
\hline 50 & Krishnan, \& Parveen (2013) & $v$ & $v$ & $v$ & & $v$ & & $v$ & & & & & & & & \\
\hline 51 & Shabeena et al. (2013) & & & & & & & & & & & $v$ & & & & \\
\hline 52 & Kumar et al. (2013) & & $\mathrm{v}$ & & & $\mathrm{v}$ & & $v$ & & & & & & & & \\
\hline 53 & Chakraborty et al. (2013) & & & & $v$ & & & & & & & & & & & \\
\hline 54 & Kumar \& Pandey (2013) & & & & $v$ & & & & & & & & & & & \\
\hline 55 & Thirunavukkarasu et al. (2013) & & & & & $v$ & & & $v$ & & & & & & & \\
\hline 56 & Khadse, Sarode and Wasu (2013) & $v$ & $v$ & $v$ & $v$ & $v$ & $\checkmark$ & $\checkmark$ & $\checkmark$ & & $v$ & & & & & \\
\hline 57 & Bhamu and Sangwan (2013) & $v$ & $v$ & $v$ & $v$ & $v$ & $\sqrt{ }$ & $v$ & $v$ & & & & & & & \\
\hline 58 & Gunasekharan et al. (2014) & & & & & $v$ & & & & & & $v$ & & & & \\
\hline 59 & Jasti \& Kodali (2014) & $v$ & $\checkmark$ & $v$ & $v$ & $\checkmark$ & $\sqrt{ }$ & $\checkmark$ & $\checkmark$ & & & & & & & \\
\hline 60 & Gupta \& Jain (2014) & $v$ & $v$ & $v$ & $v$ & $v$ & $\sqrt{ }$ & $\checkmark$ & $v$ & & & & & & & \\
\hline 61 & Sundara et al. (2014) & & & $v$ & & & $\checkmark$ & & $v$ & & & & & & & $v$ \\
\hline 62 & Aikhuele \& Azizi (2014) & & & & & & & & & & & $v$ & & & & v \\
\hline 63 & Basu \& Dan (2014) & & & & & & & & $v$ & & & & & & & \\
\hline 64 & Zargun \& Ashaab (2014) & & & & & & & & & & & $\checkmark$ & & & & \\
\hline 65 & Jadhav et al. (2014) & & & $v$ & & $v$ & $\checkmark$ & $v$ & & & & & & & & \\
\hline 66 & Obeidata et al. (2014) & & $v$ & $v$ & $v$ & & & & & $v$ & & & & & & \\
\hline 67 & Modi \& Thakkar (2014) & & & & & $v$ & & & & & & $\checkmark$ & & & & \\
\hline 68 & Jadhav et al. (2014) & $\checkmark$ & & & $v$ & & $\checkmark$ & & & & & & & & & \\
\hline 69 & Thanki \& Thakkar (2014) & $v$ & $v$ & $v$ & $v$ & $v$ & $\checkmark$ & $\checkmark$ & $v$ & & & & & & & \\
\hline 70 & Khanchanapong et al. (2014) & $v$ & $v$ & $v$ & v & $v$ & v & $\checkmark$ & $v$ & & & & & & & \\
\hline 71 & Mostafa et al. (2015) & & & & & $\checkmark$ & & $\checkmark$ & $v$ & & & & & & & \\
\hline 72 & Achanga et al. (2015) & $v$ & & & & & & & & & & & & & & \\
\hline 73 & Wan \&Chen (2015) & & $\checkmark$ & & & & & & & & & $v$ & & & & \\
\hline 74 & Cottyn et al. (2015) & $v$ & $v$ & $v$ & $v$ & & & & & & & $v$ & & & & \\
\hline 75 & Amin \& Karim (2015) & & $v$ & & & $v$ & $v$ & $\checkmark$ & & & & & & & & \\
\hline 76 & Hodge et al. (2015) & & & $v$ & & & 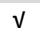 & & & V & & & & & & $v$ \\
\hline 77 & Mohammad et al. (2015) & $v$ & $v$ & $v$ & $v$ & $v$ & 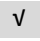 & $\checkmark$ & $v$ & & & & & & & \\
\hline 78 & Jiménez et al. (2015) & & & & & $v$ & & & $v$ & & & & & & & \\
\hline 79 & Vinodh \& Chinth (2015) & & & & & & & & $v$ & v & $\checkmark$ & $v$ & $\checkmark$ & $\checkmark$ & v & \\
\hline 80 & Parry \& Turner (2015) & & & $v$ & & & & & $v$ & & & & & & & \\
\hline 81 & Patel et al. (2015) & & & & & & & & $v$ & & & & & & & \\
\hline 82 & Pakdil \&Leonard (2015) & & & $v$ & $v$ & & & & $v$ & $v$ & & & & & & \\
\hline 83 & Eswaramoorthi (2015) & $\checkmark$ & $v$ & & $v$ & $v$ & & $\checkmark$ & & & & $v$ & & & & \\
\hline 84 & Jain et al. (2015) & $v$ & $v$ & & $v$ & $v$ & & $\checkmark$ & & & & $v$ & & & & \\
\hline 85 & Susilawati et al. (2015) & & $v$ & & & & & $\checkmark$ & & $\checkmark$ & & & & & & \\
\hline 86 & Virdi \& Pandya (2015) & $v$ & & & v & & & $\checkmark$ & & & & & & & & \\
\hline 87 & Storch (1999) & $v$ & $\checkmark$ & & $v$ & $\checkmark$ & & $\checkmark$ & & & & $v$ & & & v & \\
\hline 88 & Isaksson \& Seifert (2015) & & & & & & & & & $v$ & $v$ & & & & & \\
\hline 89 & Ozelkan \& Galambosi (2015) & & $\checkmark$ & & & & V & & & V & & & & & & \\
\hline 90 & Panwar et al. (2015) & $v$ & $v$ & & $v$ & $v$ & & $v$ & & & & $\checkmark$ & & & v & \\
\hline 91 & Gollan et al. (2015) & $v$ & $v$ & & v & $v$ & & $v$ & & & & v & & & v & \\
\hline 92 & Panizzolo et al. (2015) & & $v$ & & & $v$ & & $v$ & & & & & & & & \\
\hline 93 & Bamber \& Dale (2015) & & & $v$ & & $v$ & $\checkmark$ & $v$ & & & & & & & & \\
\hline 94 & Yang et al. (2015) & & & $v$ & & & & & $v$ & & & & & & & \\
\hline 95 & Nithia et al. (2015) & & $v$ & & $v$ & & & & & & $v$ & & & & & \\
\hline 96 & $\begin{array}{l}\text { Yang et al. (2015), Yusup et al. } \\
\text { (2015) }\end{array}$ & $v$ & $v$ & $v$ & $v$ & $v$ & $v$ & $\checkmark$ & $v$ & $v$ & $v$ & $v$ & & & & \\
\hline 97 & $\begin{array}{l}\text { Green et al. (2015); Ki \& Park, } \\
\text { (2006) }\end{array}$ & $\checkmark$ & $\checkmark$ & & $v$ & $\checkmark$ & & $\checkmark$ & & & & $v$ & & & & \\
\hline 98 & Brintrup et al. (2015) & & $v$ & & $v$ & & & & & & & & & & & \\
\hline 99 & Bortolotti et al. (2015) & & $v$ & & & $v$ & & $\checkmark$ & & & & & & & & \\
\hline 100 & Belekoukias et al. (2015) & & $v$ & & & $v$ & & $\checkmark$ & & & & & & & & \\
\hline 101 & Hartinia \& Ciptomulyonob (2015) & $v$ & $v$ & & $v$ & $v$ & & $\checkmark$ & & & $v$ & & & & & \\
\hline 102 & Niall Piercy and Nick Rich (2015) & & $\checkmark$ & & & $v$ & & & & V & & & & & & \\
\hline
\end{tabular}

Note: 1.5 'S 2. JIT 3. Kan-Ban 4. Kaizen 5. TQM 6. SMED 7. TPM 8. VSM 9. Cellular Manufacturing

10. Zero Defect Concept 11. Lean Thinking 12. WIP 13. FMS 14. Inventory Management 15. Production Leveling 


\subsection{Lean and its Strategies Implementation Barrier}

According to Roslin et al. (2014), it is easy to say that lean can be easily implemented anywhere but in practical, it is not easy. Not a single industry will go to change its complete setup without any objection because nobody wants to change until it is highly needed. Workers also suffer when system environment and trend will change. There are some barriers:

1. The main work is to maintain industry on good running condition without any disturbance but it is not possible for management as well as workers. Every little change will shine that can be good or bad (Stanleigh, 2008).

2. Accepting and sudden implementation creates a difficulty to worker. These barriers can be in form of environment, trainings, layout change, responsibility and work output. Lean thinking creates a good skill level and communication that creates a good coordination level and mutual understanding to pass all information (Roslin et al., 2014).

3. Basically, these barriers exist which mostly come out when lean is implemented, i.e.

$>\quad$ Lack of understanding between workers and managers or management to worker communication gap, and poor understanding of lean manufacturing concepts,

$>\quad$ Ego factor also a big problem for industries which is vary state to state or area to area etc.,

$>$ Non motivated employees team with incentives and good targets etc.

\subsection{Lean Manufacturing Advantages}

According to Forza (1996) and Chahal et al. (2013), lean manufacturing have more advantages over traditional system. Some reasons are discussed below that why use lean manufacturing as primary system:

\section{Table 3}

Major differences between lean and traditional manufacturing approaches

\begin{tabular}{llll}
\hline S. No & Process & Lean Manufacturing & Tradition Manufacturing \\
\hline $\mathbf{1}$ & Flexibility & High & Low \\
$\mathbf{2}$ & Inventories & As per demand & Excess demand \\
$\mathbf{3}$ & Production & Customer order & Stock \\
$\mathbf{4}$ & Layout & Product flow & Functional \\
$\mathbf{5}$ & Scheduling & Pull & Push \\
$\mathbf{6}$ & Lead time & Short & Long \\
$\mathbf{7}$ & Inspection & $100 \%$-by workers & Sampling \\
$\mathbf{8}$ & Empowerment & High & Low \\
$\mathbf{9}$ & Batch size & Small - continuous & High- batch \& queue \\
$\mathbf{1 0}$ & Customer satisfaction & High & Low \\
\hline
\end{tabular}

\section{Status of different lean strategies as per literature study}

In this article, paper shows the status about lean and lean strategies. Different papers provide different status about lean. Here it is the collection of used 102 papers' data to show how papers focus on different lean strategies. It is possible that every lean strategy will not be highlighted every time for work but most of time a single strategy can be used. So in below figure, status shows about it. Vertical side shows the number of papers out of 102 and horizontal side shows the lean strategies. 


\section{Status of different lean strategies}

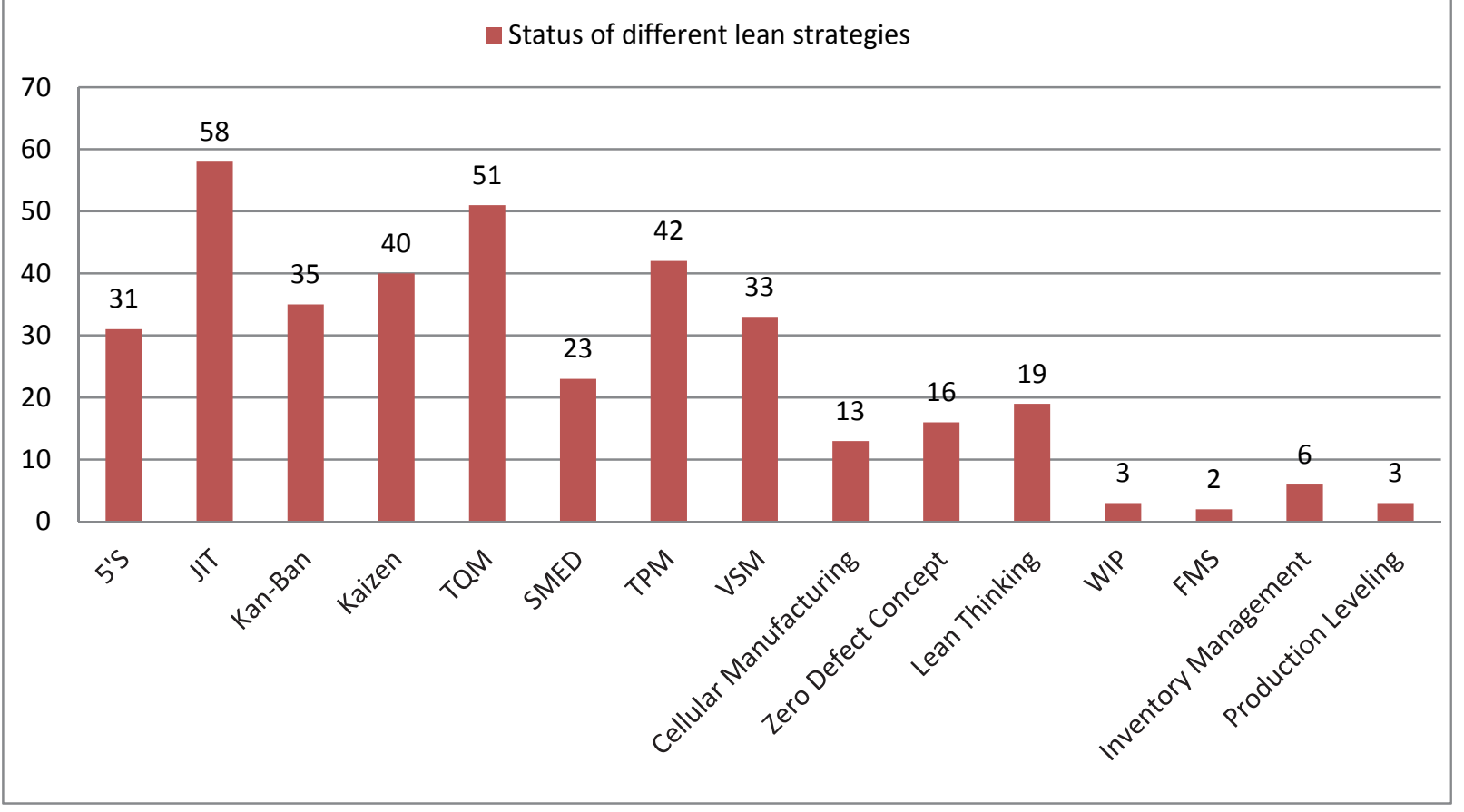

Fig. 5. Status of different lean strategies as per literature study

\section{Discussion}

Lean is a sea-depth concept in today industrial sector and also for research study. We have found that lean manufacturing concept was followed by industries as a roadmap philosophy. We have also experienced that in manufacturing sectors, lean provides a high impact theory. In this paper, different lean strategies were disused that can be implemented through providing lean training to all employees. This review paper has highlighted the status of lean and lean strategies by different author's interest. This paper is not the study of all literature review on lean strategies but it is just a try with collection of some lean papers. It's only a collection of some papers and results are based on different collecting parameters. It is just a try to give an overview on the bases of this literature. Here is also some comparison of author's interest about lean manufacturing in India and outside.

\section{Conclusion}

There is no depth of literature on lean manufacturing to give an in-depth details in actual practice and research area. It is accepted that lean manufacturing is the most profitable concept for both, manufacturing industries as well as customers so lean team prepared by different manufacturing industries (Jainury et al., 2012). All lean strategies are important at their own levels but these all are not used in all manufacturing environment. There are so many reasons like Purchasing cost, implementation time, worker training and layout change, etc. All types of industrial waste can be eliminated by these strategies (Belekoukias et al., 2014; Mabry \& Morrison, 1996; Kisombe, 2012). Here, we have used literature papers in which lean strategy was used directly or indirectly. As the result of this research paper, lean manufacturing is very much important in every area of innovation which provided lean manufacturing strategies. But there is a lack of implementation in industry. Only few strategies were implemented thoroughly as shown in Fig. 5. These are some interested strategies which are selected by their own or by default with a reason of money and time to implement. Lean strategies and their effects can be shown by case study of industry and questionnaire study which will show the actual benefit of lean. Lean manufacturing is long lasting benefit system which reduces firm and customer all over tension (Singh 
et al., 2010). As per Abdollahi et al. (2015), benefits may be in terms of waste minimization or elimination, time and money benefits, controlled overproduction and inventory, zero delay, systematic arrangement, skilled worker, less work load and best customer satisfaction, etc. but here also some barriers that discussed earlier. They are: money and time to implement, worker behavior, now every industry wants to beneficial change with lean manufacturing due to its impact on production and quality (Behrouzi , \& Wong, 2011; Begam et al, 2013; Chakraborttya \& Paul, 2011; Diaz-Elsayed et al., 2013; Chiarini, 2013; Harris et al., 2014). Overall, lean is an efficient system to give a new achievement to industry and customers.

\section{References}

Abdollahi, M., Arvan, M., \& Razmi, J. (2015). An integrated approach for supplier portfolio selection: Lean or agile? Expert Systems with Applications, 42(1), 679-690.

Abdulmalek, F. A., \& Rajgopal, J. (2007). Analyzing the benefits of lean manufacturing and value stream mapping via simulation: A process sector case study. International Journal of Production Economics, 107(1), 223-236. http://doi.org/10.1016/j.ijpe.2006.09.009

Achanga, P., Shehab, E., Roy, R., \& Nelder, G. (2012). A fuzzy-logic advisory system for lean manufacturing within SMEs. International Journal of Computer Integrated Manufacturing, 25(9), 839-852. http://doi.org/10.1080/0951192X.2012.665180

Aikhuele, D. O., \& Souleman, F. S. (2014). Australian Journal of Basic and Applied Sciences Application of Fuzzy AHP for Ranking Critical Success Factors for the Successful Implementation of Lean Production Technique, 8(December), 399-407.

Aitken, J., Christopher, M., \& Towill, D. (2002). Understanding, Implementing and Exploiting Agility and Leanness. International Journal of Logistics Research and Applications, 5(1), 59-74.

Alaskari, O., M.M., A., Dhafr, N., \& Pinedo-Cuenca., R. (2012). Critical Successful Factors (CSFs) for Successful Implementation of Lean Tools and ERP Systems. Lecture Notes in Engineering and Computer Science, 2199(1), 1627-1632.

Amin, M. Al, \& Karim, M. a. (2012). A time-based quantitative approach for selecting lean strategies for manufacturing organisations. International Journal of Production Research, 51(May 2014), 122. http://doi.org/10.1080/00207543.2012.693639

Anand, G., \& Kodali, R. (2009). Selection of lean manufacturing systems using the analytic network process - a case study. Journal of Manufacturing Technology Management, 20(2), 258-289.

Bamber, L., \& Dale, B. G. (2000). Lean production: A study of application in a traditional manufacturing environment. Production Planning \& Control, 11(3), 291-298.

Basu, P., \& Dan, P. K. (2014). Capacity augmentation with VSM methodology for lean manufacturing. International Journal of Lean Six Sigma, 5(3), 279-292.

Begam, M., Swamynathan, R., \& Sikkizhar, J. (2013). Current trends on lean management - A review. International Journal of Lean Thinking, 4(2), 1-7.

Behrouzi, F., \& Wong, K. Y. (2011). Lean performance evaluation of manufacturing systems: A dynamic and innovative approach. Procedia Computer Science, 3, 388-395.

Belekoukias, I., Garza-Reyes, J. A., \& Kumar, V. (2014). The impact of lean methods and tools on the operational performance of manufacturing organisations. International Journal of Production Research, 7543(July 2014), 1-21. http://doi.org/10.1080/00207543.2014.903348

Bhamu, J., \& Sangwan, K. S. (2014). Lean manufacturing: literature review and research issues. International Journal of Operations \& Production Management, 34(7), 876-940.

Bortolotti, T., Boscari, S., \& Danese, P. (2015). Successful lean implementation: Organizational culture and soft lean practices. International Journal of Production Economics, 160, 182-201.

Brintrup, A., Ranasinghe, D., \& McFarlane, D. (2010). RFID opportunity analysis for leaner manufacturing. International Journal of Production Research, 48(9), 2745-2764.

Chakraborttya, R., \& Paul, S. (2011). Study and implementation of lean manufacturing in a garment manufacturing company: Bangladesh perspective. Journal of Optimization in Industrial Engineering, 7, 11-22.

Chakraborty, A., Bhattacharya, M., Ghosh, S., \& Sarkar, G. (2013). Importance of kaizen concept in 
medium manufacturing enterprises. International Journal of Management and Strategy, 4(6).

Chauhan, G., \& Sharma, T. P. S. S. K. (2010). Measuring the status of lean manufacturing using AHP. Production, 1(2), 115-120.

Chiarini, A. (2013). Waste savings in patient transportation inside large hospitals using lean thinking tools and logistic solutions. Leadership in Health Services, 26(4), 356-367.

Cottyn, J., Van Landeghem, H., Stockman, K., \& Derammelaere, S. (2011). A method to align a manufacturing execution system with Lean objectives. International Journal of Production Research, 49(14), 4397-4413. http://doi.org/10.1080/00207543.2010.548409

Cua, K. O., McKone, K. E., \& Schroeder, R. G. (2001). Relationships between implementation of TQM, JIT, and TPM and manufacturing performance. Journal of Operations Management, 19(6), 675-694. http://doi.org/10.1016/S0272-6963(01)00066-3

Detty, R., \& Yingling, J. (2000). Quantifying benefits of conversion to lean manufacturing with discrete event simulation: A case study. International Journal of Production Research, 38(2), 429-445.

Diaz-Elsayed, N., Jondral, A., Greinacher, S., Dornfeld, D., \& Lanza, G. (2013). Assessment of lean and green strategies by simulation of manufacturing systems in discrete production environments. CIRP Annals - Manufacturing Technology, 62(1), 475-478.

Eswaramoorthi, M., Kathiresan, G. R., Jayasudhan, T. J., Prasad, P. S. S., \& Mohanram, P. V. (2012). Flow index based line balancing: a tool to improve the leanness of assembly line design. International Journal of Production Research, 50(12), 3345-3358.

Eswaramoorthi, M., Kathiresan, G. R., Prasad, P. S. S., \& Mohanram, P. V. (2011). A survey on lean practices in Indian machine tool industries. International Journal of Advanced Manufacturing Technology, 52(9-12), 1091-1101. http://doi.org/10.1007/s00170-010-2788-y

Forza, C. (1996). Work organization in lean production and traditional plants: what are the differences?. International Journal of Operations \& Production Management, 16(2), 42-62.

Fullerton, R. R., McWatters, C. S., \& Fawson, C. (2003). An examination of the relationships between JIT and financial performance. Journal of Operations Management, 21(4), 383-404.

Garza-Reyes, J. A., Parkar, H. S., Oraifige, I., Soriano-Meier, H., \& Harmanto, D. (2012). An empirical-exploratory study of the status of lean manufacturing in India. International Journal of Business Excellence, 5(4), 395-412. http://doi.org/10.1504/IJBEX.2012.047906

Gautam, N., \& Singh, N. (2008). Lean product development: Maximizing the customer perceived value through design change (redesign). International Journal of Production Economics, 114(1), 313332. http://doi.org/10.1016/j.ijpe.2006.12.070

Gautam, R., \& Kumar, S. (2012). Kaizen Implementation in an Industry in India : A Case Study, 5762, $25-33$.

Gollan, P. J., Kalfa, S., Agarwal, R., Green, R., Randhawa, K., Gollan, P. J., ... Green, R. (2015). Lean manufacturing as a high-performance work system : the case of Cochlear. International Journal of Production Research, 7543(December), 6434-6447. http://doi.org/10.1080/00207543.2014.940430

Gopinath, S., \& Freiheit, T. I. (2012). A waste relationship model and center point tracking metric for lean manufacturing systems. IIE Transactions, 44(2), 136-154.

Goriwondo, W. M., Mhlanga, S., \& Marecha, A. (2011). Use O F the V Alue S Tream M Apping T Ool F or W Aste R Eduction I N M Anufacturing . C Ase S Tudy for Bread Manufacturing in Zimbabwe. International Conference on Industrial Engineering and Operations Management Kuala Lumpur, Malaysia, 236-241.

Green, J. C., Lee, J., \& Kozman, T. A. (2010). Managing lean manufacturing in material handling operations. International Journal of Production Research, 48(10), 2975-2993.

Gunasekharan, S., Elangovan, D., \& Parthiban, P. (2014). A Comprehensive Study to Evaluate the Critical Success Factors Affecting Lean Concept in Indian Manufacturing Industries. Applied Mechanics and Materials, 592-594, 2569-2576.

Gupta, S., \& Jain, S. K. (2013). A literature review of lean manufacturing. International Journal of Management Science and Engineering Management, 8(4), 241-249.

Harris, G., Stone, K. B., Mayeshiba, T., Componation, P. J., \& Farrington, P. A. (2014). Transitioning from teaching lean tools to teaching lean transformation. Journal of Enterprise Transformation, 
4(3), 191-204.

Hartini, S., \& Ciptomulyono, U. (2015). The Relationship between Lean and Sustainable Manufacturing on Performance: Literature Review. Procedia Manufacturing, 4(Iess), 38-45.

Hines, P., Hines, P., Rich, N., Rich, N., Esain, A., Esain, A., ... Benchmarking, K. (1999). A distribution industry application. International Journal, 6(1), 60-77.

Hines, P., Rich, N., Hines, P., \& Rich, N. (1997). The seven value stream mapping tools. International Journal of Operations \& Production Management The, 17(1), 46-64.

Hodge, G. L., Goforth Ross, K., Joines, J. a., \& Thoney, K. (2011). Adapting lean manufacturing principles to the textile industry. Production Planning \& Control, 22(3), 237-247.

Isaksson, O. H. D., \& Seifert, R. W. (2013). Inventory leanness and the financial performance of firms. Production Planning \& Control, 25(12), 999-1014. http://doi.org/10.1080/09537287.2013.797123

Jadhav, J. R., Mantha, S. S., \& Rane, S. B. (2014). Development of framework for sustainable Lean implementation: an ISM approach. Journal of Industrial Engineering International, 10(3), 72.

Jadhav, J. R., Mantha, S. S., \& Rane, S. B. (2015). Roadmap for Lean implementation in Indian automotive component manufacturing industry: comparative study of UNIDO Model and ISM Model. Journal of Industrial Engineering International, 11(2), 179-198.

Jain, V., Benyoucef, L., \& Deshmukh, S. G. (2008). What's the buzz about moving from "lean" to "agile" integrated supply chains? A fuzzy intelligent agent-based approach. International Journal of Production Research, 46(23), 6649-6677. http://doi.org/10.1080/00207540802230462

Jainury, S. M., Ramli, R., \& Rahman, M. N. a. (2012). Applying lean principles, tools and techniques in set parts supply implementation. International Journal of Mechanical, Aerospace, Industrial and Mechatronics Engineering, 6(12), 76-80.

Jiménez, E., Tejeda, a., Pérez, M., Blanco, J., \& Martínez, E. (2012). Applicability of lean production with VSM to the Rioja wine sector. International Journal of Production Research, 50(7), 18901904. http://doi.org/10.1080/00207543.2011.561370

Karim, A., \& Arif-Uz-Zaman, K. (2013). A methodology for effective implementation of lean strategies and its performance evaluation in manufacturing organizations. Business Process Management Journal, 19(1), 169-196. http://doi.org/10.1108/14637151311294912

Khadse, P. B., Sarode, A. D., \& Wasu, R. (2013). Lean Manufacturing in Indian Industries A Review, $3(1), 175-181$.

Khanchanapong, T., Prajogo, D., Sohal, A. S., Cooper, B. K., Yeung, A. C. L., \& Cheng, T. C. E. (2014). The unique and complementary effects of manufacturing technologies and lean practices on manufacturing operational performance. International Journal of Production Economics, 153, 191203. http://doi.org/10.1016/j.ijpe.2014.02.021

Kim, D., \& Park, H.-S. (2006). Innovative construction management method: Assessment of lean construction implementation. KSCE Journal of Civil Engineering, 10(6), 381-388.

Kisombe, S. M. (2012). Lean manufacturing tools and techniques in industrial operations: A Survey of the sugar sector in Kenya. Unpublished MBA Research Project). University of Nairobi, Nairobi, 115.

Krishnan, V., \& Parveen, C. M. (2013). Comparative studyof lean manufacturing tools used in manufacturing firms and service sector. Lecture Notes in Engineering and Computer Science, 1 LNECS, 604-608.

Kumar, N., Kumar, S., Haleem, A., \& Gahlot, P. (2013). Implementing lean manufacturing system: ISM approach. Journal of Industrial Engineering and Management, 6(4), 996-1012.

Kumar, P., \& Kajal, S. (2015). Implementation of Lean Manufacturing in a Small-Scale Industry. IUP Journal of Operations Management, 14(2), 25-33.

Kumar, P., \& Pandey, V. (2013). KAIZEN : A Case study in small scale organizations, 2(May), 133136.

Mabry, B. G., \& Morrison, K. R. (1996). Transformation to lean manufacturing by an automotive component supplier. Computers \& Industrial Engineering, 31(1-2), 95-98.

Mahdiloo, M., Noorizadeh, A., \& Farzipoor Saen, R. (2014). Benchmarking suppliers' performance when some factors play the role of both inputs and outputs: A new development to the slacks-based 
measure of efficiency. Benchmarking: An International Journal, 21(5), 792-813.

Miller, G., Pawloski, J., \& Standridge, C. (2010). A case study of lean, sustainable manufacturing. Journal of Industrial Engineering and Management, 3(1), 11-32.

Modi, D. B., \& Thakkar, H. (2014). Lean Thinking: Reduction of Waste, Lead Time, Cost through Lean Manufacturing Tools and Technique. International Journal of Emerging Technologies and Advanced Engineering, 4(3), 339-344.

Mohanraj, R., Sakthivel, M., \& Vinodh, S. (2011). QFD integrated value stream mapping: an enabler of lean manufacturing. International Journal of Productivity and Quality Management, 7(4), 501522. http://doi.org/10.1504/IJPQM.2011.040546

Mostafa, S., Dumrak, J., \& Soltan, H. (2013). A framework for lean manufacturing implementation. Production \& Manufacturing Research, 1(1), 44-64. http://doi.org/10.1080/21693277.2013.862159

Naylor, J. Ben, Naim, M., \& Berry, D. (1999). Leagility: integrating the lean and agile manufacturing in the total supply chain. International Journal of Production Economics, 62, 107-118.

Nithia, K. ., Noordin, M. Y., \& Saman, M. Z. M. (2015). Lean Production Weaknesses in Manufacturing Industry: A Review. Applied Mechanics and Materials, 735, 344-348.

Obeidat, M. S., \& Pei, Z. J. (2012). Implementing Lean Manufacturing in the Sewing Industry. Industrial Systems Engineering Research Conference, 8289(November 2014), 1-8.

Ozelkan, E., \& Galambosi, A. (2009). Lampshade Game for lean manufacturing. Production Planning \& Control, 20(5), 385-402. http://doi.org/10.1080/09537280902875419

Paez, O., Dewees, J., Genaidy, A., Tuncel, S., Karwowski, W., \& Zurada, J. (2004). The lean manufacturing enterprise: An emerging sociotechnological system integration. Human Factors and Ergonomics In Manufacturing, 14(3), 285-306. http://doi.org/10.1002/hfm.10067

Paez, O., Salem, S., Solomon, J., \& Genaidy, A. (2005). Moving from lean manufacturing to lean construction: Toward a common sociotechnological framework. Human Factors and Ergonomics In Manufacturing, 15(2), 233-245. http://doi.org/10.1002/hfm.20023

Pakdil, F., \& Leonard, K. M. (2014). Criteria for a lean organisation: development of a lean assessment tool. International Journal of Production Research, 52(15), 4587-4607.

Panizzolo, R., Garengo, P., Sharma, M. K., \& Gore, A. (2012). Lean manufacturing in developing countries: evidence from Indian SMEs. Production Planning \& Control, 23(10-11), 769-788.

Parry, G., \& Turner, C. (2006). Application of lean visual process management tools. Production Planning \& Control, 17(Janeiro 2006), 77-86. http://doi.org/10.1080/09537280500414991

Patel, N., Chauhan, N., \& Trivedi, P. (2015). Benefits of Value Stream Mapping as A Lean Tool Implementation Manufacturing Industries: A Review. IJIRST-International Journal for Innovative Research in Science \& Technology, 1(8), 53-57.

Pattanaik, L. N., \& Sharma, B. P. (2009). Implementing lean manufacturing with cellular layout: A case study. International Journal of Advanced Manufacturing Technology, 42(7-8), 772-779.

Pekuri, A., Herrala, M., Aapaoja, A., \& Haapasalo, H. (2012). Applying Lean in Construction Cornerstones for Implementation. Proceedings for the 20th Annual Conference of the International Group for Lean Construction.

Pettersen, J. (2009). Defining lean production: some conceptual and practical issues. The TQM Journal, 21(2), 127-142. http://doi.org/10.1108/17542730910938137

Poksinska, B. (2010). The current state of Lean implementation in health care : literature review. Quality Management in Health Care, 19(4), 319-329.

Rajenthirakumar, D., \& Thyla, P. (2011). Transformation to lean manufacturing by an automative component manufacturing company. International Journal of Lean Thinking, 2(2), 1-13. Retrieved from http://www.ita.mx/files/gui-ingles-tecnico-nov-2012/ing-industrial-2-11-2012-1.pdf

Ramnath, B. V., Elanchezhian, C., \& Kesavan, R. (2010). Application Of Kanban System For Implementing Lean Manufacturing (A Case Study). Journal of Engineering Research and Studies, I(I), 13.

Rose, A. N. M., Md. Deros, B., \& Ab. Rahman, M. N. (2013). A study on lean manufacturing implementation in Malaysian automotive component industry. International Journal of Automotive and Mechanical Engineering, 8(1), 1467-1476. http://doi.org/10.15282/ijame.8.2013.33.0121 
Roslin, E. N., Shamsuddin, A., \& Dawal, S. Z. M. (2014). Discovering Barriers of Lean Manufacturing System Implementation in Malaysian Automotive Industry. In Advanced Materials Research (Vol. 845, pp. 687-691). Trans Tech Publications.

Sahoo, A. K., Singh, N. K., Shankar, R., \& Tiwari, M. K. (2008). Lean philosophy: Implementation in a forging company. International Journal of Advanced Manufacturing Technology, 36(5-6), 451462.

Satao, S. M., Thampi, D. G. T., Dalvi, S. d., Srinivas, B., \& Patil, B. T. (2012). Enhancing Waste Reduction through Lean Manufacturing Tools and Techniques, a Methodical Step in the Territory of Green Manufacturing. IRACST - International Journal of Research in Management \& Technology (IJRMT), 2(2), 253-257.

Schwarz, P., Pannes, K. D., Nathan, M., Reimer, H. J., Kleespies, A., Kuhn, N., ... Z??gel, N. P. (2011). Lean processes for optimizing or capacity utilization: Prospective analysis before and after implementation of value stream mapping (VSM). Langenbeck's Archives of Surgery, 396(7), 10471053. http://doi.org/10.1007/s00423-011-0833-4

Seyedhosseini, S. M., Taleghani, A. E., Bakhsha, A., \& Partovi, S. (2011). Extracting leanness criteria by employing the concept of Balanced Scorecard. Expert Systems with Applications, 38(8), 10454 10461. http://doi.org/10.1016/j.eswa.2011.02.095

Shah, R., \& Ward, P. T. (2003). Lean manufacturing: Context, practice bundles, and performance. Journal of Operations Management, 21(2), 129-149.

Singh, B., Garg, S. K., \& Sharma, S. K. (2010). Development of index for measuring leanness: study of an Indian auto component industry. Measuring Business Excellence, 14(2), 46-53.

Singh, B., Garg, S. K., Sharma, S. K., \& Grewal, C. (2010). Lean implementation and its benefits to production industry. International Journal of Lean Six Sigma, 1(2), 157-168.

Soriano-Meier, H., \& Forrester, P. L. (2002). A model for evaluating the degree of leanness of manufacturing firms. Integrated Manufacturing Systems, 13(2), 104-109.

Stanleigh, M (2008). Effeting successful changemanagment initiatives, Industrial and commercial training, 40, 34-37

Stewart, S., \& Adams, M. (1998). The lean manufacturing champion: reducing time and risk by encouraging risk-taking. Strategic Change, 7(6), 357-366.

Storch, R. L. (1999). Improving flow to achieve lean manufacturing in shipbuilding. Production Planning \& Control, 10(February 2015), 127-137. http://doi.org/10.1080/095372899233280

Sundar, R., Balaji, A. N., \& Satheesh Kumar, R. M. (2014). A review on lean manufacturing implementation techniques. Procedia Engineering, 97, 1875-1885.

Susilawati, A., Tan, J., Bell, D., \& Sarwar, M. (2015). Fuzzy logic based method to measure degree of lean activity in manufacturing industry. Journal of Manufacturing Systems, 34(C), 1-11.

Thirunavukkarasu, S., Bheeman, B. V, Ashwin, R., Varadharajan, M., Devadasan, S. R., \& Murugesh, R. (2013). Lean implementation through value stream mapping: A case study in an Indian pump manufacturing company. International Journal of Services and Operations Management, 16(4), 506-524. http://doi.org/10.1504/IJSOM.2013.057511

Vamsi, N., Jasti, K., \& Kodali, R. (2014). A literature review of empirical research methodology in lean manufacturing. International Journal of Operations \& Production Management, 34(10), 1080 1122. http://doi.org/10.1108/IJOPM-04-2012-0169

Vinodh, S., \& Balaji, S. R. (2011). Fuzzy logic based leanness assessment and its decision support system. International Journal of Production Research, 49(13), 4027-4041.

Vinodh, S., \& Chintha, S. K. (2011a). Application of fuzzy QFD for enabling agility in a manufacturing organization: A case study. The TQM Journal, 23(3), 343-357.

Vinodh, S., \& Chintha, S. K. (2011b). Leanness assessment using multi-grade fuzzy approach. International Journal of Production Research, 49(2), 431-445.

Vinodh, S., \& Joy, D. (2012). Structural Equation Modelling of lean manufacturing practices. International Journal of Production Research, 50(6), 1598-1607.

Vinodh, S., \& Vimal, K. E. K. (2012). Thirty criteria based leanness assessment using fuzzy logic approach. International Journal of Advanced Manufacturing Technology, 60(9-12), 1185-1195. 
Vrijhoef, R., \& Koskela, L. (2000). The four roles of supply chain management in construction. European Journal of Purchasing \& Supply Management, 6(3-4), 169-178.

Wan, H.-D., \& Chen, F. F. (2008). A leanness measure of manufacturing systems for quantifying impacts of lean initiatives. International Journal of Production Research, 4623(23), 6567-6584.

Wong, W. P., Ignatius, J., \& Soh, K. L. (2012). What is the leanness level of your organisation in lean transformation implementation? An integrated lean index using ANP approach. Production Planning \& Control, 25(4), 273-287. http://doi.org/10.1080/09537287.2012.674308

Yang, M. G., Hong, P., \& Modi, S. B. (2011). Impact of lean manufacturing and environmental management on business performance: An empirical study of manufacturing firms. International Journal of Production Economics, 129(2), 251-261. http://doi.org/10.1016/j.ijpe.2010.10.017

Yang, T., Hsieh, C.-H., \& Cheng, B.-Y. (2011). Lean-pull strategy in a re-entrant manufacturing environment: a pilot study for TFT-LCD array manufacturing. International Journal of Production Research, 49(6), 1511-1529. http://doi.org/10.1080/00207540903567333

Yang, T., Kuo, Y., Su, C. T., \& Hou, C. L. (2015). Lean production system design for fishing net manufacturing using lean principles and simulation optimization. Journal of Manufacturing Systems, 34(1), 66-73. http://doi.org/10.1016/j.jmsy.2014.11.010

Yusup, M. Z., Mahmood, W. H. W., Salleh, M. R., \& Yusof, A. S. M. (2015). Review the influence of Lean tools and its performance against the index of manufacturing sustainability. International Journal of Agile Systems and Management, 8(2), 116-131.

Zanjirchi, S. M., Tooranlo, H. S., \& Nejad, L. Z. (2010). Measuring Organizational Leanness Using Fuzzy Approach. Proceedings of the 2010 International Conference on Industrial Engineering and Operations Management, 144-156.

Zargun, S., \& Al-Ashaab, A. (2013). Critical Success Factors for Lean Manufacturing: A Systematic Literature Review an International Comparison between Developing and Developed Countries. Advanced Materials Research, 845, 668-681.

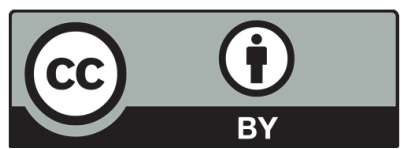

(C) 2017 by the authors; licensee Growing Science, Canada. This is an open access article distributed under the terms and conditions of the Creative Commons Attribution (CC-BY) license (http://creativecommons.org/licenses/by/4.0/). 